\title{
The Credit Policies and Credit Finance Creation Practices by Commercial Banks in Ghana: Perspectives of Staff and Clients of the Prudential Bank Limited
}

\author{
John Kwaning Mbroh ${ }^{1}$, KwesiAsiedu Koomson ${ }^{2}$ \\ ${ }^{1}$ Dept. of Accountancy Studies,School of Business \&Mgt Studies,Cape Coast Polytechnic,Cape Coast, Ghana \\ ${ }^{2}$ KNUST CEMBA Program,KNUST Kumasi,Ghana \\ Email address: \\ jaykaynews@yahoo.co.uk(J. K.Mbroh),jmbroh@cpoly.edu.gh(J.K.Mbroh), thekoomsons@yahoo.com(K. A.Koomson)
}

\section{To cite this article:}

John KwaningMbroh, KwesiAsieduKoomson. The Credit Policies and Credit Finance Creation Practices by Commercial Banks in Ghana: Perspectives of Staff and Clients of the Prudential Bank Limited. International Journal of Economics, Finance and Management Sciences. Vol. 3, No. 5, 2015, pp. 441-452. doi: 10.11648/j.ijefm.20150305.15

\begin{abstract}
Commercial banks play a crucial role in credit financing of individuals, institutions and generally, their clients. They use a system of credit management to govern their operations in this regard. Specifically, they do this through established credit policies or systems and to an extent, the relevant policy determines a given quantum of credit finance on case-by-case basis but most importantly, whether or not to grant the credit finance request upon assessment. Conveniently sampling the perspectives of both credit officers (15) and customers (67) of the Prudential Bank Limited, primary and secondary data sources were used, with the primary data obtained through unstructured interviews and two sets of self-administered questionnaire for the respective respondent-categories. The findings reveal that both categories of respondents recommend the need for the bank to decentralise its credit finance application processing and approval system. Due to the bank's existing credit policy, customers had to wait, on average, one month for the approval or otherwise of their requests, with the salariedworker customer-group granted more credit finance than the others. Also, the bank had granted more credit in the form of loans. Sadly, business persons and other categories of customers were waiting three months for response to their credit finance requests. The customers and their bankers disagreed in their respective perspectives regarding the main reason(s) for granting or declining credit finance requests as well as on matters of collateral security. Among others, the study recommends the shortening of credit facility processing time to enhance the bank's competitive drive in the banking industry and also to make these facilities more responsive to the needs of the customers. Future research is expected to conclude on the extent of impact that banks' credit policies have on their credit finance creation.
\end{abstract}

Keywords: Credit Policy, Credit Finance Creation, Credit Officers, Customers, Prudential Bank Limited (PBL)

\section{Introduction}

Financial institutions, like the commercial banks, have become a reliable source of funding businesses, individuals, entities and so on. It is undisputed that in Ghana, the banking sector plays an intermediating role in both capital concentration and distribution. They do this by primarily offering credit finance in the form of loans, advances, overdrafts and so on. Being credit facilities, the banks rely on their established policies and procedures to regulate the funds. Frequently, the term 'credit policy' is used in this endeavour. However, Finlay (2009), noted that the word, 'credit', comes from the Latin credo translated "I believe". Indeed, it is the trust that allows one party to provide resources to another party where that second party does not reimburse the first party immediately (thereby generating a debt) but instead, arranges either to repay or return those resources (or other materials of equal value) at a later date. The resources so provided may be financial, consist of goods or services (see also Sheffrin, 2003; and Ingham, 2004).On the other hand, Miller (1999)argued that the word, 'policy', can be a broad and frightening term especially as most institutions having their peculiar policies, procedures and guidelines define them on their own terms. Furthermore, while it is widely appreciated that there is the need for these institutions to have a workable set of regulations, the word 'policy' carries some 
negative connotations of bureaucracy and inflexibility (see also Thompson, Jr., et al, 2005).

Fact is that the amount and frequency of financial credit offered by these banks, depends to a greater extent, on the terms and application of the respective credit policies practised by a bank on one hand, and the reception and responsiveness to the credit policies by the clients on the other hand. This situation calls for a relationship based on extreme mutual understanding and benefits. The commercial banks hold the much needed funds by their clients but upon certain conditions (prudential measures) been met, whilst the clients, as valued customers, need the funds from the banks but only upon satisfying laid-down conditions. These necessary conditions are the credit policies. In his view, Bullivant (2010) suggested that credit policy should start at the highest level, agreed at all levels and be inclusive of all those areas of the business operation which leads to satisfying customer requirements (see also Thompson, Jr., et al, 2005; Finlay, 2009). The credit policies are designed to govern the available credit funds, credit created or credit finance by banks. Stoop (2010), defined credit creation as the act or process of creating either: (a) the facility of being able to obtain goods or services before payment, based on trust that payment will be made in the future; or (b) an entry in an account recording a sum received.

Engaged in stock brokerage, funds management, corporate finance, business advisory services as well as in equity and economic research, is the Prudential Securities Limited, one of the two wholly owned subsidiaries of the Prudential Bank Limited (PBL). Incorporated as a private limited liability company in 1993 under the Companies Code, Act 179, the PBL has since then grown with 29 branches and 2 agencies throughout Ghana. Its other subsidiary, the PBL Properties Limited was established to acquire and develop banking premises for the bank and also to manage the auxiliary staff of the bank. Having a vision to provide both domestic and international banking services with a strategic focus on project financing and export development, the PBL is committed to play a positive and an innovative roles in the financial intermediation process and most importantly, to offer the best and the most remunerative banking services to the business community. Indeed, quality, creativity and innovation are the hallmarks of the PBL (Koomson, 2013).

Common knowledge has it that loans and advances make up the highest earning assets of commercial banks, though most risky as well, in banking operations. In view of this, whilst the temptation may persist to maximise overall earnings, it may rather be prudent always to maintain a tradeoff between such earning maximisation and the maintenance of adequate liquidity levels to avert any consequent liquidity crises. In this venture, the commercial banks allege that largely, their clients do not comply with their credit policies (credit terms and conditions) and the result of which is extreme caution on their part in giving out the facilities. In contrast, the clients allege that they co-operate in this regard but rarely get the needed credit finance (in the form of loans, overdrafts, advances and so on) to support their operations due to bureaucracies emanating from excessive prudential measures by the banks. These scenarios into perspective, this study examine the existing credit policies and credit finance creation by commercial banks in Ghana using the perspectives of both staff and customers of the PBL.

SIGNIFICANCE OF THE STUDY: Efficient and reliable banking operations aid in creating a viable financial system upon which the development agenda of a country is propelled. Every sector of an economy has a relationship with these banks. They serve as a pivot and a crucial source of inter-connectivity with both domestic and foreign operations in these respects (see also, Werner, 2005). Domestically, they enhance personal, corporate and other financial management, existence and growth to a greater extent. Specifically, they help in personal and corporate capital formation and utilisation. The clients rely on banking services and in some cases, bankers' advice, to grow financially from one level to another whilst the banks, like other businesses, solely exist for their clients. Similarly, Drucker (1974) observed that businesses have changed and are changing as a result of a focus on the customer and that a business must first be able to create a customer. However, the banks' clients frequently require credit assistance for one reason or another in their endeavours. Practically, no business can afford to run solely on cash or equity basis at all volumes and years of operations. In his view, Mbroh (2011) noted that no business can afford to buy all the materials required for the manufacture of goods for sale with cash. In some cases they have to negotiate with suppliers for credit and in most cases, businesses succeed in procuring stock on a short-term credit basis. Somehow, the bank-clients inter-dependency hinges on the extent on cohesion attained on the crucial subject of credit policy when it comes to the provision of credit finance (see also Bullivant, 2010). With several documented studies on the subjects of credit policy and credit creation notwithstanding, this study attempts to highlight the specific importance of the two in a bank-customer relationship. The results are not only intended to contribute to the literature on both subjects but also to create a basis for further studies to validate any possible inter-dependence of the two.

\section{Objectives of the Study and Research Questions}

In order to appreciate the need for commercial banks' prudential measures (credit policies) and consequently, their credit finance creation, it would be pertinent firstly, to explain the nature and types of credit finance they offer, the necessary pre-conditions as well as the basis of the banks' decision-making in these respects. Significantly related to these dynamics, are the respective perspectives held by the customers and their bankers on the decision-making in this regard, especially, those relating specifically to customerunderstanding and response. Equally important, is how these practices consequently affect the bank-clients' relationship 
regarding the provision of these facilities and their demands respectively by the parties. Also crucial is the clients' overall assessment of the bank's operations in these respects. Secondly, it would be helpful to identify the basis of assessing clients in terms of their credit-worthiness or basis for good credit scoring and the bank's decision in this regard. What decision factor(s) really enhance(s) or constrain(s) this encounter? Do the credit policies inhibit creation of credit finance or otherwise? Thirdly, it is would useful to establish the crucial importance of the consequence of the relevant application of credit policies in creating the credit finance by the banks' in a manner that either influences good or bad perceptions by their clients. What attributes are expected to enhance their mutual understanding and benefits? Again, how do customers perceive the process and timing, availability or otherwise of collaterals and related policy pre-conditions in this venture?

\subsection{Literature Review}

Broadly, the subject of credit management has been severally documented. For instance, Bullivant (2010) observed that credit management or credit risk management refers to systems, procedures and controls which a company has in place to ensure the efficient collection of customer payments and minimise the risk of non-payment. Indeed, it requires a sound understanding of the basics so as to: know the financial ability of customers; assess how much credit to allow; process orders quickly; and collect funds on time. Obviously, credit policy and credit finance creation are distinct aspects of credit management. However, there seem to be an inter-dependency of some sort regarding these two terms. The 'policy' governs how the 'finance' is disbursed. In other words, where there is no credit finance, there cannot be a credit policy and as a result, each does not exist in isolation but relies on the very existence of the other. What remains unknown, however, is the extent of influence on each other in this seeming relationship.

\subsection{Credit Policy Defined}

According to McMenamin (1999), the management of account receivables essentially begins with the decision whether to grant credit to a customer and if so, how much and on what terms. This is consequently the logical starting point for the institution of a credit policy since the credit policy includes all the company's systems and procedures governing the determination of: credit selection; credit standards; credit terms; and the collection policy. Touching on the subject, Attom and Mbroh (2012) referred to a credit policy as the established procedure for extending credit and collecting debts owed by customers of the firm. In their view, once a firm decides to grant credit to its customers, it should establish a credit policy to effectively deal with recalcitrant debtors. On his part, Bullivant (2010) suggested that credit policy should start at the highest level, agreed at all levels and be inclusive of all those areas of the business operation which leads to satisfying customer requirements. Similarly,
Finlay (2009) observed that a typical credit policy will address the following points: credit limits; credit terms; deposits; credit cards and personal checks; customer information; and documentation. In the view of Thompson Jr., et al (2005), a credit policy may be explained as the guidelines that spell out how to decide which customers are sold on open account, the exact payment terms, the limits set on outstanding balances and how to deal with the delinquent account.

\subsection{Credit Finance Creation}

Evidence of credit finance creation, on the other hand, traces over 5000 years back in history, when Temples had often acted as banks in the ancient Babylon $\left(3^{\text {rd }}\right.$ Millennium BC). Werner (2005) maintains that for many centuries, banks have served as the main creators of the money supply, with ancient Egypt, Greece and Rome using their banking systems to supply their economies with money through credit creation (see also, Schumpeter, 1954; Haln, 1920; and Wicksell, 1898).

\subsection{Commercial Banks' Credit Finance Creation}

The banks have a standard procedure or step-by-step process for creating credit finance which differs from textbook representation of credit (see Stoop, 2010; and Werner, 2005).

\subsection{The Standard Representation of Credit Creation by Banks}

On the asset side of the balance sheet, banks hold reserves and loans. The liabilities consist of debt and equity. When a customer makes a deposit at a bank, it is listed as debt. The following illustrative tables (Its) explain the process.

IT 1. Banks balance sheet.

\begin{tabular}{ll}
\hline Bank's balance sheet & \\
\hline Assets & Liabilities \\
Reserves & Debt \\
Loans & Equity \\
\hline
\end{tabular}

Source: Stoop (2010).

The equality of assets and liabilities required leads to Equation 1: Equation 1: $\mathrm{R}+\mathrm{L}=\mathrm{D}+\mathrm{E}$. Where: $\mathrm{R}=$ Reserves; $\mathrm{L}=$ Loans; $\mathrm{D}=\mathrm{Debt}$; and $\mathrm{E}=$ Equity. To illustrate the credit creation process of banks in the fractional reserve banking system, let us assume that equity is 0 and the reserve requirement $\mathrm{RR}$ is 0.1 ( $10 \%$ of the deposits must be held as reserves).

Bank A receives a deposit of GHS1,000 (IT 2).

IT 2.Step 1 (credit creation process by Werner).

\begin{tabular}{lc}
\hline Bank A \\
\hline 100 & 1000 \\
900 & \\
\hline
\end{tabular}

Source: Stoop (2010). 
Bank A keeps GHS100 as reserves and extends loans to Bank B of GHS900 (IT 3).

IT 3. Step 2 (credit creation process by Werner).

\begin{tabular}{ll}
\hline Bank B & \\
\hline 90 & 900 \\
810 & \\
\hline
\end{tabular}

Source: Stoop (2010).

Bank B has now GHS900 on the liabilities side of the balance sheet. Based on this debt, Bank B leaves GHS90 as reserve and extends 810 as a loan to Bank C (IT 4).

IT 4. Step 3 (Bank C receives a loan from Bank B).

\begin{tabular}{ll}
\hline Bank C & \\
\hline 81 & 810 \\
729 & \\
\hline
\end{tabular}

Source: Stoop (2010).

This process can go on until the extendable loan goes to zero. Table 5 shows that the total amount of money has grown from an original of GHS1,000 to GHS10,000 after ' $n$ ' steps.

IT 5. Credit creation process in $n$ steps (credit creation by Werner).

\begin{tabular}{lllll}
\hline Bank & LiabilitiesDeposits & AssetsCredits & Reserves & $\begin{array}{c}\text { Total } \\
\text { assets }\end{array}$ \\
\hline $\begin{array}{l}\text { Bank } \\
\text { A }\end{array}$ & 1,000 & 900 & 100 & 1,000 \\
$\begin{array}{l}\text { Bank } \\
\text { B }\end{array}$ & 900 & 810 & 90 & 900 \\
Bank & 810 & 729 & 81 & 810 \\
C & & & & \\
- & & & & \\
- & & 0 & 0 & 0 \\
Bank $\mathrm{n}$ & 0 & 9,000 & 1,000 & 10,000 \\
\hline
\end{tabular}

Source: Stoop (2010).

We may recall how credit creation is usually represented in textbooks. It is a process of intermediation where money is created via lending and re-lending. Only after ' $n$ ' steps, an original deposit of GHS1,000 can grow to GHS10,000. The first Bank A could only extend loans of GHS900. Werner (2005) proposes what he considers a more accurate representation of credit creation. In a first step, Bank A receives a deposit of GHS1,000 by a customer (Table 6). The deposit is found on the debt side of the bank's balance sheet.

IT 6. Step 1 (Credit Creation process by Werner: Deposit).

\begin{tabular}{rr}
\hline Bank A \\
\hline \\
\hline
\end{tabular}

Source: Stoop. (2010).

The GHS1,000 of Bank A can now be used to increase the reserves of Bank A (IT 7).
IT 7. Step 2 (Credit creation process by Werner: Reserves of bank A).

\begin{tabular}{ll}
\hline Bank A & \\
\hline 1000 & 1000 \\
\hline
\end{tabular}

Source: Stoop. (2010).

With a reserve requirement of $10 \%$, Bank A can now directly extend GHS9,000 in loans (IT 8). The created credit of GHS9,000 is not based on previous savings - the money comes from nowhere. Thus, Bank A created an additional money supply of GHS 9,000 , which is $90 \%$ of the total money supply of GHS10,000 in this isolated economy.

IT 8. Step 3 (Credit creation process by Werner: money created).

\begin{tabular}{ll}
\hline Bank A & \\
\hline 1000 & 9000 \\
9000 & 1000 \\
\hline
\end{tabular}

Source: Stoop (2010).

The long process of lending and re-lending is not necessary. Other than commonly represented in textbooks, Bank A does not lend out GHS9,000 of the originally received deposit. Instead, Bank A uses the GHS1,000 as reserve with the central bank (entered as an asset on the balance sheet). The GHS1,000 is now used as the new reserve and based on this reserve; new loans amounting to GHS9,000 can be extended. Each individual bank can create credit and money. Where do the additional GHS9,000 come from? Werner (2005) answers the question as follows: "The money was not withdrawn by the bank from other uses. It was not diverted or transferred from any other part of the economy. Most of all, although it is shown as a deposit, it was not actually deposited by anyone. The bank simply created the money by writing the figures into its books and the customer's account book. In effect, the bank pretends that its borrower has made a deposit that was not actually made. Unlike the textbook representation, we see that each individual bank can thus create money when it extends a loan".

\subsection{Types of Credit Finance and Securities Managed by the Banks}

The Banking Law of 2004 (Act 673) spells out clearly what the banks can do regarding credit finance and the consequences for not complying for not operating within the specified limits. Specifically, Part VI of the Act (Act 673) spells out secured and unsecured as main types of lending and associated with each type are the required securities as outlined. According to Ayernor (2011), the banks usually look for some of security when granting loans to customers, though there have long been anomalies in the attitude of banks to consumer customers and to trade customers. Similarly, banks look for personal guarantees from proprietors or directors of small companies to support even modest overdrafts, while at the same time their credit card divisions have allowed unsecured limits of such larger value. Precisely, when a bank takes security over a customer's property or other asset(s) before granting credit finance, it is 
secured credit finance and the reverse is true. A bank shall not grant any advances, loans or credit facilities including guarantees, against the security of: its own shares; the shares of its holding company; the shares of any of its subsidiaries; or the shares of any of the subsidiaries of its holding company (The Banking Law, 2004).Also, a bank shall not take financial exposure in respect of any one person or a group of persons which constitutes in the aggregate, a liability to the bank amounting to more than $25 \%$ of the net own funds of the bank. However, this does not apply to transactions between banks and licensed non-banking financial institutions except otherwise specified by the Bank of Ghana (the Central Bank).

According to the Law (Act 673), the limits of the aggregate of unsecured financial exposure shall not exceed $10 \%$ of the bank's net own funds. A bank shall not take unsecured financial exposure in respect of any of its: directors or significant shareholders; firms or companies in which a director or a significant shareholder is interested as director, controlling shareholders/partner or proprietor, employee or guarantor; holding or subsidiary companies of the company in which a director is interested in; or directors' relatives or significant shareholders' relatives, unless the prior written approval of the Bank of Ghana (BoG) is obtained in respect of that unsecured exposure. Where the financial exposure is on secured basis, the aggregate liability to the bank in respect of a director or significant shareholder or their related parties, indicated above, shall not exceed $10 \%$ of the bank's net own funds.

By law, the board of the respective commercial bank shall be the only authority to approve or sanction any financial exposures of the bank to any of its directors or significant shareholders or related parties specified earlier and such financial exposure of a bank shall not be written-off or waived fully or partially, without the sanctions of the respective bank's board with prior approval in writing from the BoG. In all these, a bank which contravenes the provisions shall pay to the $\mathrm{BoG}$, a fine of 1000 penalty units. Relatives include spouse, son, daughter, step-child, brother, sister, father and mother (The Banking Law, 2004).

\subsection{The Credit Policy, Lending Approval and Related Subjects - the Case of PBL}

It is alleged that the fundamentals of the credit policy of the PBL recognises the fact that under-funding a business (or client) is equally as harmful as over funding. In view of this, the PBL Credit Policy Document (2010) specifies that "the bank shall always ensure that it is in a position to satisfy the justified credit needs of its customers in full, provided that in so doing, it shall not infringe the prudential limits imposed on the banks by the banking law. For this reason, the maximum unsecured credit facility and/or guarantee that the bank may grant to any one customer at any point in time shall not exceed $10 \%$ of the bank's net-worth, and for fully secured facility, $25 \%$ of the net-worth. In situations where a customer's credit need is in excess of the permissible limit, the bank may, whenever feasible, endeavour to syndicate the facility with other banks".

Sourcing similarly, the PBL requires adequately secured credit facilities granted to customers and the security may be in the form of a principal or collateral or both with a security margin of $100 \%$ or more being the most acceptable. Nevertheless, in special cases when the risk of default is perceived to be minimal, the bank may accept lower levels of coverage. It is common knowledge that customers with good banking track record of debt service may enjoy some degree of concession in the provision of security. Again, security requirement may also be relaxed at the discretion of management for credit finance (facilities) granted under special credit schemes such as the Prudential Business Savings Account (PBSA), Prudential Welfare Savings Account (PWSA), Salaried Workers Loan Scheme (SWLS), Special Credit Schemes for Exporters of Non-traditional export commodities (NTE) and Group Exporters. By similar discretion, the bank may lend to multinational companies and AAA-rated companies such as Unilever Limited and AngloGold Ashanti Company Limited which by policy and practice borrow unsecured.

The PBL accepts the following forms as security: assets that are financed out of the proceeds of the credit and may extend to the company's existing assets (these represent principal security); cash, government stocks, shares of reputable companies, treasury bills and assignment of deposit accounts; life assurance policies; a regularly maintained marketable landed property or recourse to specified rights by the bank; personal guarantees from persons with sound financial standing shall be acceptable for loan and overdraft amounts not exceeding GHS10,000 in addition to another security; assignment of stocks, vehicles and sales/contract proceeds; and directors' guarantee with non-Ghanaian directors expected to have verifiable assets.

The Credit Policy Document of PBL (2010) states that the maximum repayment period for a short-term business or personal loans shall be 36 months whilst overdrafts shall be 12 months. Project and mortgage loans shall have repayment periods of up to 20 years inclusive of grace period. Regarding loan rescheduling/restructuring however, the bank decision(s), focusing on the strengths and weaknesses of the borrower's business and other viable justifications, shall be based on a credit review report by an Account Manager or Credit Officer through the Credit Executive Committee. Specifically, the loan rescheduling may be considered for projects or businesses that experience any one of the following phenomena: time overrun during implementation of the business activity that is financed by the bank resulting in delay in starting up the business; delay in delivery of goods and services ordered or imported by the borrower; negative deviation of cash from the projected figures contained in the credit report due to the fact that reasonable time period is required to set up production and build up sales; and inadequate cash flow generation due to seasonal slowdown in business activity.

The Credit Policy Document (2010) spells out 3 levels of lending or credit approving authority at the PBL as follows: 
the Credit Sub-Committee (deals with credit finance levels not exceeding GHS10,000); Executive Committee (deals with credit finance levels up to the cedi equivalent of 1million USD); and the Board of Directors (with the ultimate approval powers in line with the outlined bank's regulations and in compliance with the Banking Law or the necessary prudential measures relating to the respective limits).

Determining the credit worthiness of a bank client is crucial in this endeavour. Ghana's financial system lacks a robust and responsive clients' credit scoring system at the moment. However, as a practice, Ayernor (2011) stated that commercial banks in Ghana including the PBL, circulate banker's opinion to solicit for customers' indebtedness to sister banks. In his view, McMenamin (1999) noted that a common approach to determining a customer's credit worthiness is by analysis and use of the ' $5 \mathrm{Cs}$ ' of credit (capacity, capital, character, collateral and condition) as an initial screening and risk assessment devise. Similarly, Coyle (2008) had the mnemonics CAMPARI and ICE as a means of assessing the credit worthiness or otherwise of a customer. This is interpreted is character, ability, means, purpose, amount, repayment, insurance (CAMPARI) with interest, charges, extras (ICE). Other easily memorable tools include the 3Cs (character, capability and capital); 4Cs (character, capability, capital and connection); PARSERS (person, amount, repayment, security, expediency, remuneration and service); CRIS (character, repayment, incentive and security); and IPARTS (integrity, purpose, amount, repayment, terms and security).

\subsection{Credit Finance Creation by the PBL}

The credit finance created by the PBL can be categorised into two, namely the funded and non-funded. Ayernor (2011) explains the PBL funded credit finance as including financing types that make available funds or cash to the borrower for utilisation with its source funding usually being deposits mobilised by the bank or funds from lines of credit. They disbursed to clients in form of loans and overdrafts. The loans are of various types and include personal loans, project loans, working capital loans, stand-by loans, revolving loans, mortgage loans and export finance loans. On the other hand the overdrafts are normally granted to supplement working capital for commercial, service or production activities.

Similarly, Ayernor (2011) differentiates the non-funded credit finance as facilities not involving the provision of funds or cash initially to the customer for utilisation. However, a liability or debt may occur as a result of a bank providing a non-funded banking facility to a customer upon its eventual benefit to the customer. Typical assigned examples include bid bonds, bonds security, performance bond, letters' of credit, letters' of intent, letters' of trust, letters' of comfort, advance payment guarantees, contingent liabilities, and indemnity.

\subsection{Credit Finance Documentation and Credit Risks by the $P B L$}

Legal documents frequently executed by both the bank and clients (based on existing credit policy) covering credit finance facilities include: heads of agreement (for all clientgroups incorporating all the terms and conditions on the facility granted); shareholders' resolution (unnecessary where the borrower's stated capital is in excess of amount being borrowed); directors' guarantee; personal guarantee; partner guarantee; indemnity; mortgage; mortgage and general charge; assignment and charge; assignment of movables (vehicles, stock-in-trade, etc); assignment of cash security (PBSA, PWSA, treasury bills, savings accounts, foreign and local currency, etc); and consent to mortgage for mortgagors (Ayernor, 2011). Aside these documents, the bank does monitoring of clients' account operations as a back-up prudential measure in this regard using several tools, techniques and procedures (see also Koomson, 2013).

Clearly, the importance of both credit policy and credit finance creation devoid of merely yes or no offer decisions have not been explored. Using the perspectives of staff and customers of the PBL, the study attempts to examine the unique roles of both credit policy and credit finance creation in banks' credit management systems.

\section{Methodology}

The study was conducted on commercial banks in Ghana with the PBL as the case study. Quite broadly, it examined the how the banks manage their credit operations in specific areas of credit policy and credit finance creation as well as make the case for a future study to validate their possible interdependence on each other. Using unstructured interviews and questionnaires, data was collected from both primary and secondary sources with the secondary sources being annual reports of PBL showing the bank's credit risk, credit reports (brief write up on applicants' financial, marketing and competition analysis), the reason for requesting for the facility, call and monitoring report (which spells out discussions on the customer's business operations) after the credit finance (facility) has been granted. Others relied upon include heads of agreement (which stipulates the rights and obligations of both the bank and the beneficiary of the credit finance) and the general terms, the letter of guarantee (which spells out the obligations of the guarantor) as well as the offer letters. Finally on the secondary data sources were seminars, training and course materials by the PBL training school.

Specifically on the unstructured interviews, were informal interactions with some credit finance applicants and credit officers of PBL. The questionnaires were in two sets. One set elicited information from customers of PBL particularly those who had ever applied for any form of credit finance from the bank. Other questions in this set sought to collect information on the forms of security provided by customers, the time it took for their application's approval or otherwise, what the customers want to see improved in the PBL's credit operations as well as the customers' understanding of the terms of the credit finance (eg. loan contract). The other set 
of questions was for the PBL credit officers (staff). It focused on ascertaining the availability (existence) of credit policy and its operational adequacy and as to whether or not they abide by the tenets of such policy document. Also included but not limited to, were how the bank managed her credit finance, to what extent has the implementation of the existing policy helped or otherwise in credit finance creation by the bank as well as the bank's basis for determining a customer's credit worthiness and of facility approval or otherwise.

The study wanted to use the entire population but because of time, access to both suitable sites and respondents, a convenience sampling technique was used to obtain a representative and statistically valid sample from the population. Specifically, both account and non-account holders of the PBL who have ever applied for credit facility form the population of the study. It is worthy of note that the non-account holders could access credit finance from PBL under a scheme loan facility operated by the bank.

Using a convenience sampling technique, the authors administered the questionnaires on customers who were present at the visited branches of the PBL and had applied for credit finance (facilities) from the PBL in the past, regardless of the specific type of credit finance. Due to the regimented or routine way of operations, a sample total of 50 of the respective respondents' categories would be enough to arrive at a reasonable conclusion of the study. However, regarding the customer-category, a total of 80 questionnaires were distributed but 67 of them responded. The credit officers (branches) of PBL contacted were 20 but 15 responded. Descriptive statistical tools in the form of frequency and percentages tables were used in the data analysis.

\section{Results and Analysis}

Overall, 82 respondents made up of 67 credit finance applicants (customers) and 15 of the bank's credit officers (bank staff) were involved in the study (Table 1). At the time of the study the PBL, one of the renowned commercial banks in Ghana, had existed and operated continuously for 17 years. The study revealed that a well-documented credit policy existed and was updated in the year 2010 (PBL Credit Policy Document, 2010) with trained staff assigned to administer its operation in all branches of the bank, supervised by both top management and clearly defined three-tier committee structure. The academic and professional backgrounds of the credit officers ranged from Diploma to Master's degrees levels including some professionally (CIB, ACCA, ICA) part-qualified.

\subsection{Gender Participation of Respondents}

Table 1. Response per gender.

\begin{tabular}{llll}
\hline $\begin{array}{l}\text { Response } \\
\text { category }\end{array}$ & Male (f/ \%) & Female (f/ \%) & Total (f/ \%) \\
\hline Customers & $41(61)$ & $26(39)$ & $67(81.7)$ \\
Bank staff & - & - & $15(18.3)$ \\
\hline Sample size(f/ \%) & $41(61)$ & $26(39)$ & $82(100)$ \\
\hline
\end{tabular}

Source: Authors' fieldwork, Jan. 2015.

The gender differences were sought with respect to the customer-respondents. Specifically, $61 \%$ of these respondents were males and 39\% females (see results in Table 1). Even though, the study did not probe the careers, trades or businesses of the respective gender respondents, Mbroh and Assah (2015) had concluded that there were more females $(53 \%)$ in the micro business segment and more males $(60 \%)$ in the small business segment in Ghana.

\subsection{Type of Credit Finance Offered by the PBL; Successful Applications or otherwise; and Associated Collateral Matters by the PBL}

The credit finance created by the PBL can be categorised into two, namely the funded and non-funded. According to Ayernor (2011), the PBL funded credit finance include financing types that make available funds or cash to the borrower and they are disbursed to clients in form of loans and overdrafts. Those of the non-funded credit finance (facilities) do not involve the provision of funds or cash initially to the customer for utilisation. Results (see Table 2) show that $82 \%$ and $18 \%$ of the respondents received the funded and non-funded types of credit finance respectively offered by the bank. On its part, Table 3shows two conditions for their respective gender responses regarding the credit finance applications. These were: 'did you obtain the loan'; and the 'forms of security used'. Overall, $16 \%$ of applications were rejected or declined, $64 \%$ and $36 \%$ of the successful applicants were males and females respectively. Again, 25\% of the successful applicants did not use any form of collateral security. Regarding those who used a form of collateral, $67 \%$ and $33 \%$ were males and females respectively.

Table 2. Type of credit finance offered by the $P B L$.

\begin{tabular}{ll}
\hline Type credit finance & Freq. (\%) \\
\hline Funded & $46(82)$ \\
Non-funded & $10(18)$ \\
\hline Sample size (f/\%) & $56(100)$ \\
\hline
\end{tabular}

Source: Authors'fieldwork, Jan. 2015.

Table 3.Credit finance application success or otherwise, with or without collateral.

\begin{tabular}{llllll}
\hline \multirow{2}{*}{ Question } & \multicolumn{2}{l}{ Successful (f/ \%) } & & \multicolumn{2}{c}{ Rejected (f/ \%) } \\
\cline { 2 - 5 } & Male & Female & No collateral & Sub total & Row Total (f/ \%) \\
\hline Did you obtain the loan? & $36(64)$ & $20(36)$ & - & $56(84)$ & $11(16)$ \\
Did you use collateral? & $28(50)$ & $14(25)$ & $14(25)$ & $56(84)$ & $11(16)$ \\
\hline
\end{tabular}

Source: Authors' fieldwork, Jan. 2015. 
Table 4. Collateral type demanded per credit finance.

\begin{tabular}{lllll}
\hline \multirow{2}{*}{ Collateral type demanded } & \multicolumn{3}{l}{ Specific type of credit finance (f/ \%) } & \multicolumn{2}{c}{ Row total } \\
\cline { 2 - 5 }$(\mathbf{f} / \mathbf{\%})$
\end{tabular}

Source: Authors' fieldwork, Jan. 2015.

Overall (see Table 4), loans were the most offered (62\%) form of credit finance by the bank with the least being overdrafts (14\%). Similarly, own-savings and/or business banking records was most utilised form of collateral by majority of applicants. However, regarding the specific types of credit finance sought, majority $(73 \%)$ of the loan applicants had either relied on salaried-worker guarantee or their landed properties.

\subsection{Main Perspectives on Either Granting or Declining a Credit Finance Facility}

There are several perspectives on banks' decisions to either offer or decline credit finance to clients. For instance, Eyiah (2001) blamed the neglect or decline of credit finance on banks'reliance on excessive prudential policies (see also the conclusions of Bbenkele, 2007; Binks et al, 1992; Boots \& Thakor, 1994; Schoombee, 2007; Seal, 1998; Mbroh, 2012; and IFC, 2000).Indeed, the banks' have held different perspectives in these respects by frequently citing policy or procedural reasons. Largely on their part, customers are alleged to have widely held the view of been treated unfairly, especially when they are declined a credit facility. In a related view, all the two categories of respondent's perspectives were sought in this regard and they held different views (see Table 5). Regarding the main reason for declining credit finance, majority $(67 \%)$ of the bank officials cited applicants' poor credit scoring (rating) and weak financial capacity as the basis. In contrast, majority (58\%) of the customers (all participants) stated that they either did not know or were uncertain about the cause.

Similarly, the results (in Table 6) show the main respective perspectives of granting and receiving credit finance by bankers and customers respectively. Majority of the bank officials maintained that they granted credit finance facilities based on customers' financial capacity to repay, followed by applicant's banking records upon monitoring. On their part, majority of customers felt that they either do not know or are uncertain about the basis of being granted credit finance facilities and this was followed by the understanding that credit finance are granted based on applicant's capacity to repay.

Table 5.Position on main reason(s) for rejected applications (loans declined).

\begin{tabular}{|c|c|c|}
\hline \multirow{2}{*}{ Reason(s) } & \multicolumn{2}{|c|}{ Respondent category (f/ \%) } \\
\hline & Bank staff & Customers \\
\hline Incomplete application (lack of supporting documents) & $3(20)$ & - \\
\hline Impossible request & $2(13)$ & $17(25.4)$ \\
\hline Poor credit scoring/rating and capacity & $10(67)$ & - \\
\hline Unknown/uncertain reasons & - & $39(58.2)$ \\
\hline Told, I couldn't repay & - & $7(10.4)$ \\
\hline Due to collateral demands & - & $4(6)$ \\
\hline
\end{tabular}

Source: Authors' fieldwork, Jan. 2015.

Table 6. Position on bank's major decision factor in granting credit finance.

\begin{tabular}{lll}
\hline \multirow{2}{*}{ Decision factor(s) } & \multicolumn{2}{l}{ Respondent category (f/ \%) } \\
\cline { 2 - 3 } & Bank staff & Customers \\
\hline Depending on specific credit finance & $3(20)$ & $5(7.5)$ \\
Depending on capacity to repay & $7(46.7)$ & $17(25.4)$ \\
Depending on customers' banking records & $4(26.7)$ & $11(16.4)$ \\
Depending on customer loyalty & $1(6.6)$ & $8(11.9)$ \\
Unknown/ uncertain & - & $26(38.8)$ \\
\hline Sample size (f/ \%) & $15(100)$ & $67(100)$ \\
\hline
\end{tabular}

Source: Authors' fieldwork, Jan. 2015.

\subsection{Assigned Challenges with Credit Finance Applications by Respondent-Category}

A credit finance facility is an off-shoot of a system of credit management. Indeed, the credit management system establishes and governs the credit policy, credit finance levels and associated conditions, procedure(s) as well as the approval criteria. However, the emphasis here is on the system of applying for a credit finance facility.In this situation the system relates both internally (credit officers/management) and externally (customers/regulators). As a result, the challenges associated with the application system may differ in the perspectives of the two respondentgroups (bank staff and customers alike). Fact is that the bank generates the system as a guide in its credit finance operations with the customers, who in turn, are expected to comply with the system's requirements. However, in keeping with this relationship, Brandi et al (2006) caution that every 
business, large and small, depends on customers for its livelihood but surprisingly, a great many businesses fail to honour this common-sense principle. In support, Mbroh (2011) noted that a business operation should factor-in the reaction of customers. The main challenge forwarded by the bank's credit officers was the fact that frequently, credit finance applicants lacked the necessary financial capacity to repay the facility they were seeking (see also Mbroh \& Quartey, 2015). On the other hand, majority of the customers cited the main challenge they faced with their credit finance applications as unknown bureaucratic processes within the bank that delays their response having presented the application.

Table 7.Main challenge(s) with credit finance applications by respondents.

\begin{tabular}{lll}
\hline \multirow{2}{*}{ Application challenge(s) } & \multicolumn{2}{l}{ Respondent category (f/\%) } \\
\cline { 2 - 3 } & Bank staff & Customers \\
\hline Compliance with credit policy document & $5(33.3)$ & - \\
Lack of capacity to repay & $8(53.3)$ & - \\
Falsification of application records & $2(13.3)$ & - \\
Non-existent loan request brochure & - & $12(17.9)$ \\
Non-existent loan request preparation & - & $14(20.9)$ \\
assistance & - & $10(14.9)$ \\
Uncertain time-lag & - & $20(29.9)$ \\
Unknown associated bureaucracy & - & $11(16.4)$ \\
Non-existent appeals system & $15(100)$ & $67(100)$ \\
\hline Sample size (f/\%) & & \\
\hline
\end{tabular}

Source: Authors' fieldwork, Jan. 2015.

\subsection{Customer-Perceptions on Facility-Decision Time-lag and Bureaucratic Challenges}

Customers rely on banking services and in some cases, bankers' advice, to grow financially from one level to another whilst the banks, like other businesses, solely exist for their clients. Drucker (1974) observed that businesses have changed and are changing as a result of a focus on the customer and that a business must first be able to create a customer. However, in this specific situation, customers frequently require credit finance assistance for one reason or another but most importantly, based on time-lines. Already, customers, largely, have negative perceptions on the willingness of the banks to grant them credit finance (see Christain, 2005: Bbenkele, 2007; Schoombee 2007). Indeed, if the associated time-line purposes are not carefully considered and the credit finance eventually granted, the benefits, if any, to the customer would certainly not be the same. On their part, the IFC (2000) maintained that “...lack of expertise in the banks...and the risks associated with lending to less-established entrepreneurs means that smaller companies in the region often cannot access the cash they need to develop and expand. In this instance however, the credit officers of PBL have at least, adequate academic backgrounds. The study recognises the possibility of time-lag and bureaucratic challenge differences with respect to the bank's customer categories. In view of this, the responses were sought in these respects (see Table 8). Regarding the time-lag challenges, majority $(69 \%)$ of the salaried-worker respondents stated that it took 1 month to be offered credit finance. On their part, many of the business persons (41\%) and the 'others' (70\%) said they had their loans in 3months. However, overall, majority of the respondents stated that they were offered credit finance in a month by the bank. The respondents, regardless of category, felt that the bank had excessively complex bureaucratic credit finance process devoid of their needs and urgency. This, they further assert, resulted in a situation where in anticipation of their request being granted often resort to other expensive sources and pay-off (the expensive sources) upon approval by PBL. Indeed, their situation worsens if in the long-run they are declined.

Table 8. Customer perception on time-lag and bureaucratic challenges.

\begin{tabular}{|c|c|c|c|c|}
\hline \multirow{2}{*}{ Perceived time-lag challenge } & \multicolumn{4}{|c|}{ Customer category (f/ \%) } \\
\hline & Salaried workers & Business persons & Others (individuals, churches, societies, etc) & Row total \\
\hline Two weeks for an offer letter & $3(8.6)$ & $2(9.1)$ & - & $5(7.5)$ \\
\hline One month for an offer letter & $24(68.6)$ & $7(31.8)$ & $2(20)$ & $33(49.3)$ \\
\hline Three months for an offer letter & $6(17.1)$ & $9(40.9)$ & $7(70)$ & $22(32.8)$ \\
\hline Unknown/ uncertain period for offer letter & $2(5.7)$ & $4(18.2)$ & $1(10)$ & $7(10.4)$ \\
\hline Sample size (f/ \%) & $35(52.2)$ & $22(32.8)$ & $10(14.9)$ & $67(100)$ \\
\hline \multirow{2}{*}{$\begin{array}{l}\text { Perceived bureaucracy with credit finance } \\
\text { application (assistance) }\end{array}$} & \multicolumn{4}{|c|}{ Customer category (f/ \%) } \\
\hline & Salaried workers & Business persons & Others (individuals, churches, societies, etc) & Row total \\
\hline Normal or acceptable process & $5(14.3)$ & $2(9.1)$ & - & $7(10.4)$ \\
\hline Quite complex and worrying process & $9(25.7)$ & $6(27.3)$ & $2(20)$ & $17(25.4)$ \\
\hline Excessively complex devoid of our needs & $21(60)$ & $14(63.6)$ & $8(80)$ & $43(64.2)$ \\
\hline Sample size (f/ \%) & $35(52.2)$ & $22(32.8)$ & $10(14.9)$ & $67(100)$ \\
\hline
\end{tabular}

Source: Authors' fieldwork, Jan. 2015.

\subsection{Customers' Overall Reaction to the Bank's Credit Policy and Credit Finance}

Table 9. Customers' overall reaction(s) to existing credit policies and credit finance by the PBL.

\begin{tabular}{lllll}
\hline \multirow{2}{*}{ Customers' reactions } & \multicolumn{2}{l}{ Customer category (f/\%) } \\
\cline { 2 - 5 } & Salaried workers & Business persons & Others (individuals, churches, societies, etc) & Row total (f) \\
\hline 1.Shorter facility processing time & $35(100)$ & $22(100)$ & $10(100$ & 67 \\
2.Decentralised (branch) approval system & $35(100)$ & $22(100)$ & $10(100$ & 67 \\
\hline
\end{tabular}




\begin{tabular}{lllll}
\hline \multirow{2}{*}{ Customers' reactions } & \multicolumn{2}{l}{ Customer category (f/\%) } & \\
\cline { 2 - 5 } & Salaried workers & Business persons & Others (individuals, churches, societies, etc) & Row total (f) \\
\hline 3.Education/literature on credit system & $35(100)$ & $22(100)$ & $10(100)$ & 67 \\
4.Method(s) of assessing credit worthiness & $35(100)$ & $22(100)$ & $10(100)$ & 67 \\
\hline
\end{tabular}

Source: Authors'fieldwork, Jan. 2015.

Every business worth its sort must aim to constantly attract and win the trust of its customers in order to retain them for its going-concern. According to Drucker (1974), in today's marketing orientation era, it is recognised that meeting customer needs is the foundation of any successful business and that the customer comes first, second and third. In support, Hannagan (1998) observed among others, that customers have, of course, always been important; what has changed is the priority given to them and the urgency with which their needs are considered. The caution is that customer service is now the factor which distinguishes one business from another within an industry since customers now have become demanding with more choice. The results in Table 9 show the general views, perhaps expectations, of the customers, regardless of category, on PBL products and services this regard. Overall, four major issues of equal expectations by customers are: a shorter facility processing and offer period than the existing; a decentralised (branch level) facility approval system; provision of adequate education, literature and communication on the credit system; and open (transparent) method of assessing customer-credit worthiness. Specifically on the issue of assessing customer credit worthiness, the study found that the PBL basically grants credit finance to businesses based on known and acceptable integrity and expertise of their managers. In some cases, they grant these facilities based on sufficient appraisal of their financial performance. However, new businesses are assessed based on three consecutive years audited accounts in addition to report from banker's opinion (from other banks) exercise on their credit worthiness. Others include customer's cash flows and their bank account operation (banking records).

\subsection{Credit Officers'Assessment of the Bank'S Credit Policy and Credit Finance}

Respondents in this regard have been with the bank for several years with relevant training added to their adequate academic backgrounds and their attained experience(s) working with the bank. Having sought the views of the customers, the credit officers, as direct operators of the credit system were posed cross-tab kind of questions independently. Under four independent propositions, the respondents were asked the same expectations by the customers in turns and the results, averaged in the end (Table 10). Regardless of the proposition on the existing credit policy, the credit officers agree to the call by customers for the PBL to decentralise the credit finance facility (or at least, up to a certain limit as done in other banks) at the branch level. This was followed by the consideration to shorten the existing period for facility processing and approval. Where the existing credit policy inhibits the creation of adequate credit finance, the respondents expect that bank to still decentralise and shorten the processing period. They maintain however, that in an event where the existing credit policy does not create credit finance, all the customer expectations will be worth urgent consideration. Merely relying upon the PBL Annual Reports for the financial year ended, 2011 and 2012, the respondents maintained that the existing credit policy had created adequate credit finance, as a result of which there are significant increases in the total credit finance facilities granted to customers year after year. This claim, however, needs appropriate study to validate the exact impact or relationship between a given credit policy and credit finance creation.

Table 10. Credit officers'views about PBL's existing credit policies and credit finance creation.

\begin{tabular}{|c|c|c|c|c|c|}
\hline \multirow[b]{2}{*}{ Credit officers' response } & \multicolumn{5}{|c|}{ Reactions per assertion (proposition) } \\
\hline & $\begin{array}{l}\text { Reasonable } \\
\text { credit policy }\end{array}$ & $\begin{array}{l}\text { Challenging } \\
\text { credit policy }\end{array}$ & $\begin{array}{l}\text { Credit policy enhances } \\
\text { credit creation }\end{array}$ & $\begin{array}{l}\text { Credit policy not } \\
\text { improving credit creation }\end{array}$ & $\begin{array}{l}\text { Average } \\
\text { response (f/\%) }\end{array}$ \\
\hline 1. Shorter facility processing time & $10(67)$ & $7(47)$ & $15(100)$ & $15(100)$ & $47(78)$ \\
\hline 2.Decentralised (branch) approval system & $15(100)$ & $15(100)$ & $15(100)$ & $15(100)$ & $60(100)$ \\
\hline 3.Education/literature on credit system & $8(53)$ & $10(67)$ & $11(73)$ & $10(100)$ & $39(65)$ \\
\hline 4.Method(s) of assessing credit worthiness & $8(53)$ & $12(80)$ & $10(67)$ & $15(100)$ & $43(72)$ \\
\hline Sample size - staff (f/ \%) & $41(68.3)$ & $43(71.7)$ & $51(85)$ & $60(100)$ & $189(78.8)$ \\
\hline
\end{tabular}

Source: Authors'fieldwork, Jan. 2015.

\section{Conclusion and Recommendations}

The study concludes that the PBL has always had a clearly authored credit policy governing its credit management practices with the existing one reviewed in the year 2010 . Assigned credit officers normally have adequate academic backgrounds with the needed experience and training by the bank. However, real processing and approval of the credit finance applications are done at the head quarters (centralised). The bank provides two categories of credit finance facilities in the form of funded $(82 \%)$ and nonfunded $(18 \%)$. The funded credit finance involves financing that make available funds or cash to the borrower and they are disbursed to clients in form of loans, advances and overdrafts. Those of the non-funded credit finance (facilities) do not involve the provision of funds or cash initially to the 
customer for utilisation. Overall, $84 \%$ of credit finance applications were granted with $62 \%$ mostly offered as loan form of credit finance by the PBL. While majority of the bank officials stating that the credit finance applications were granted based on capacity to repay, many of the customers maintained that they did not know the exact basis.

Also, overall, $16 \%$ of the respondents were declined their loan applications and there were varying reasons per each respondent-category. Majority $(58 \%)$ of the customerrespondents attributed uncertain or unknown reasons for being declined their requests. Credit officers, in contrast, cited applicants' poor credit rating and weak financial capacity as the basis. Overall, own-savings or clients' banking records was the most utilised form of collateral by majority of applicants. However, regarding the specific types of credit sought, majority of applicants had either relied upon salaried-worker guarantee or their landed properties. $25 \%$ of successful applicants did not provide any collateral security. The customer-respondents' main challenge with the existing credit policy (system), was the bureaucratic processes within the bank that create undue delays in loan acquisitions. Majority of the credit officers' rather cited frequent lack of clients' capacity to repay such facilities which mostly made things difficult for both parties. Overall, customerrespondents stated that they spent, on average, a month to receive their facility offer letters (this includes salaried workers), though business persons and 'other category' of customers noted that it took 3 months to receive their offer letters. Regardless of their categories, customers maintained that the bank had excessively complex bureaucracy devoid of their needs and timing. They consequently expected shorter facility processing time, decentralised approval system, adequate education (including literature) on the credit system and transparent method of assessing customer credit worthiness. Presently, the study concludes that a combination of the CAMPARI and ICE, PARSERS and 4Cs are used by PBL.

The credit officers agree to the call by customers for the PBL to decentralise the credit finance facility (or at least, up to a certain limit as done in other banks) at the branch level. This was followed by the suggestion to shorten the existing period for facility processing and approval. Where the existing credit policy inhibits the creation of adequate credit finance, the respondents expect that bank to still decentralise and shorten the processing period. They maintain however, that in an event where the existing credit policy does not create credit finance, all the customer expectations will be worth urgent consideration. Merely relying upon the PBL Annual Reports for the financial years ended, 2011 and 2012, the bank's (staff) assertion that the existing credit policy had created adequate credit finance, due to significant increases in the total credit finance facilities granted to customers year after year, needs appropriate study to validate the exact impact or relationship between a given credit policy and credit finance creation.

The study is recommends an urgent review of the existing credit policy to shorten the credit facility processing time to enhance the bank's competitive drive within the commercial banking industry. Again, a situation where credit facility approvals are sanctioned from headquarters must be reviewed in order to cut-down on the unnecessary bureaucracies and existing delays in order to make these much needed facilities more responsive to the needs of the customers. An enhanced transparent relationship with effective communication founded on the principle of interdependence and mutual benefits between the bank and its customers is recommended. Again, the banks are expected to operate open-door service policy (for example, using the suggestion box system, open forum, after-service interviews and questionnaires, and such means) to gather relevant information from their clients regarding poorly offered products and delivered services in order to swiftly adapt and remain competitive in the sights of its customers and competitors. Indeed, in this era of technological advancement, changes and competition, they are expected to keenly focus on always satisfying customers by offering competitive choices in terms of their products and services.

On their part, the customers are recommended to rise up to the occasion by presenting their challenges appropriately with emphasis and follow up in order to get them addressed speedily and as mutually beneficial as possible. This way, perhaps slowly but sure, they will be getting their challenges addressed one after the other. They are also expected to be well-informed and equipped by obtaining the necessary information on the bank's products and services as well as the associated terms and conditions so as to plan accordingly. Who knows? This may offer them unique opportunities to be met at least, half-way, in their financial emergencies. Future research is expected to study the impact of credit policy on credit finance creation by commercial banks in Ghana. Emphasis may be placed on either an omnibus or credit finance policy specifics exist. Again, main challenges faced by both the banks and customers in this endeavour may also be worth investigating.

\section{References}

[1] Attom, B.E. and J.K. Mbroh (2012). Financial Management Made Easy: A Self-Tuition Approach, Accra:Adwinsa Publications (Gh) Ltd.

[2] Ayernor, H.T. (2011). Seminar on Types of Credit Facilities Available in Prudential Bank Limited, PBL Training School, Accra.

[3] Bbenkele, E.K. (2007). An Investigation of Small and Medium Enterprises Perceptions Towards Services Offered by Commercial Banks in South Africa, African Journal of Accounting, Economics, Finance and Banking Research, Vol.1, No.1, pp13-25.

[4] Binks, M., Ennew, C. and G. Reed (1992). Information Asymmetry and the Provision of Finance to Small Firms, International Small Business Journal, Vol.11, No.11, pp.35-46.

[5] Boots, A. and A. Thakor (1994). Moral Hazards and Secured Lending in an Infinitely Repeated Credit Market Games, International Economic Review, Vol.35, No.4, pp.899-920. 
[6] Brandi, J., Hyden, H. and C. Reeves (2006). Best Practices: Customer Retention, TEC Inc., p.1.

[7] Bullivant, G. (2010).Credit Management,6th ed., Ashgate Publishing Limited.

[8] Christain, G.A. (2005). Micro Enterprise Alliance: http//www.mea.org.za (accessed 15/12/14)

[9] Coyle, B. (2008).Corporate Credit Analysis, EPP Book Series.

[10] Credit Policy Document (2010). The Prudential Bank Limited, (October).

[11] Drucker, P. (1974). Management: Tasks, Responsibilities and Practices, New York: Harper \& Row.

[12] Eyiah, A. (2001). An Integrated Approach to Financing Small Contractors in Developing Countries: A Conceptual Model, Construction Management Journal, Vol.19, pp.511-518.

[13] Finlay, S. (2009).Consumer Credit Fundamentals, Palgrave, MacMillan.

[14] Haln, L.A. (1920/1949a). The Economics of Illusion: A Critical Analysis of Comtemporary Economic Theory and Policy, New York:Squire Publishing.

[15] Hannagan, T. (1998). Management Concepts and Practices, London:Financial Times and Pitman.

[16] http//www.prudentialbank.com(accessed 10/12/14).

[17] IFC (2000). IFC Program to Boost Africa Small Business Lending, The IFC.

[18] Ingham, G. (2004).The Nature of Money, Policy Press Limited

[19] Koomson, K.A. (2013). The Impact of Credit Policies on Credit Creation: A Case Study of Prudential Bank Limited, Unpublished CEMBA Dissertation, IDL, KNUST, Kumasi.

[20] Mbroh, J.K.(2011). Methods of Accounting Practices by Small Business Owners in the Cape Coast Metropolitan Area of Ghana, Journal of Polytechnics in Ghana, Vol.5, No.1, pp.129151

[21] Mbroh, J.K. (2012). An Investigation of Small and MicroEnterprise Owners' Perception Towards Financial Credit Offered by Commercial Banks in the Cape Coast Metropolitan Area, Asian Economic and Financial Review, Vol. 2 No.1, (March), pp. 171-180.
[22] Mbroh, J.K. and B. Assah (2015). Financial Records Keeping and Business Decision-Making Practices by Small and Micro Enterprise Owners in Ghana - Evidence from the Central Region, International Journal of Economics, Commerce and Management, United Kingdom, Vol.3, Issue 8, (August), pp.467-491.

[23] Mbroh, J.K. and S. Quartey (2015). The Funding Cycle of Small and Micro Enterprises In Ghana - Evidence of StageBy-Stage Sources and Challenges from The Central Region, International Journal of Economics, Commerce and Management, United kingdom, Vol.3, Issue 8, (August), pp.290-314.

[24] McMenamin, J. (1999). Financial Management: An Introduction, London:Routledge, pp.617-627.

[25] Miller, C. (1999).Credit Policy, A Presentation to Credit Research Foundation(CRF),

[26] Oxford Journals-the Quarterly Journal of Economics, Vol.109,Issue2, pp.399-441.

[27] Schoombee, A. (2000). Development South Africa, (December), Vol.17, No.3, pp.751-767.

[28] Schumpeter, J.A. (1942). Creative Destruction:From Capitalism, Socialism and Democracy, New York: Harper Row, pp.82-85.

[29] Seal, W.B. (1998). Relationship Banking and the Management of Organising Trust, International Journal of Banking Marketing, Vol.16, No.3, pp.102-107.

[30] Sheffrin, S.M. (2003).Economics: Principles in Action, Pearson Prentice Hall

[31] Stoop, M. (2010). Credit Creation and its Contribution to Financial Crises,Master Thesis, D-MTEC.

[32] The Banking Law of Ghana (2004). The Act 673.

[33] Thompson, et al (2005).Crafting and Executing Strategy-The Quest for CompetitiveAdvantage, McGraw-Hill.

[34] Werner, R.A. (2005).New Paradigm in Macroeconomics, Solving the Riddle of Japanese Macroeconomic Performance, Palgrave, MacMillan.

[35] Wicksell, K. (1898). Interest and Prices, London 1936: Macmillan. 